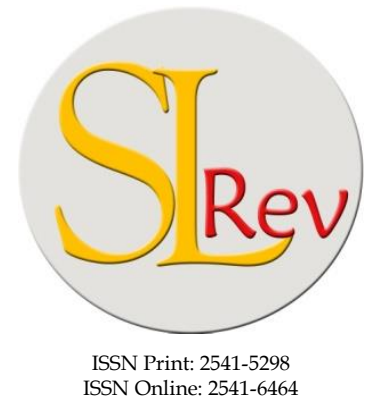

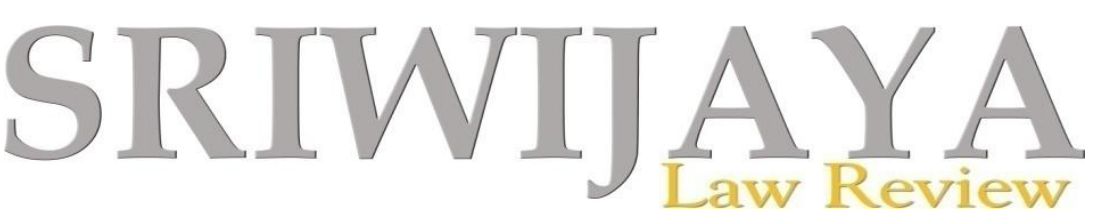

Editorial Office: Faculty of Law, Sriwijaya UniversityJalan Srijaya Negara, Palembang, South Sumatra 30139, Indonesia. Phone: +62711-580063Fax: +62711-581179

E-mail: sriwijayalawreview@unsri.ac.id| sriwijayalawreview@gmail.com

Website: http://journal.fh.unsri.ac.id/index.php/sriwijayalawreview

\title{
General Overview on Selecting and Drafting Construction Contract Disputes Resolution
}

\author{
Meria Utama* and Irsan*
}

\begin{abstract}
A good international contract as the experts considered is the most complicated one the parties must draft carefully. It involves many stakeholders and containing documents to attach likewise financial judgment, technical specifications, work scope, rights, obligation, responsibility and other external factors which are beyond the parties' consideration. A good design contract will prevent the parties from disputes. The dispute settlement mechanisms should be explicitly stated in the international construction contract. The nullity of the choice dispute settlement mechanisms or in the absence of the choice dispute settlement mechanisms and also the unperformed of the contract purposes will not prevent the dispute from being occurred. The most common process to resolve disputes is through litigation, but the process takes time, energy and funding. The method of alternative dispute resolution (ADR) such as mediation, conciliation, mini-trial, arbitration or other ADR techniques eradicate all the obstacles above. The question arises then, how the parties select the best alternative disputes settlement mechanism and how it should be drafted in their contract. Normative legal research is the method employed to respond the problems. Therefore, this article will elaborate the methods that will effectively settle the constructions disputes and mechanism in drafting construction contract disputes resolutions provisions.
\end{abstract}

Keywords: ADR; Construction Contract; Disputes Settlement Clause.

\section{ARTICLE HISTORY:}

\section{DOI: 10.28946/sIrev.Vol2.Iss2.129.pp152-169}

Received: Mar 31, 2018;

Reviewed: Jul 2, 2018;

Accepted: Jul 23, 2018;

Published: Jul 31, 2018;

Citation: V.2.2 SLRev. 2018.

Faculty of Law, Universitas Sriwijaya, E-mail: meriautama@yahoo.co.id

\section{INTRODUCTION}

A contract in legal term is an agreement that the law will enforce. A typical construction contract contains at least two reciprocal promises namely contractor promises to perform a work specified in the contract, and owner promises to pay the con- tractor for that work. In addition, the contract generally contains a number of other promises related to the parties' obligations. Construction contract sometimes considered as a complicated contract because this contract is not a single document but consist of a group of contract documents. These contract documents typically include the scope of work, the quality of the work, the project schedule, the project budget, and each party's rights and remedies if the other party breaches its obligations. The contract documents may also include soil reports or others engineering data. One or more of the contract documents (usually the agreement 
and/or the general conditions) will define the documents comprised to the contract. ${ }^{1}$ Then, the complexity involved in a construction project contracts are typically written and executed (signed) by both parties. $^{2}$

The parties demand their contract to be performed as well as the right and obligation of the contract must be strictly applied in accordance with its term. A party cannot be compelled to accept performance at variance with that for which it is bargained. There are three kinds of construction contracts performance such as substantial performance, partial performance and approval of performance. These performances depend on clauses arranged in the contract per $s e .{ }^{3}$ Breaches of contract take place when a promisor, without sufficient excuse or justification, fails to perform in accordance with the terms of his agreement. ${ }^{4}$

In past decade, researches and studies has been undertaken and already indicated that construction dispute is one of the fundamental causes of project failure besides any other causes by some common recognition i.e., limited construction time, lack of operation fund, unpredictable disaster, poor site management, unforeseeable shortage of material supply, design change, underestimate of tender price, currency fluctuation,

1 Alan E Harris, "Alternative Dispute Resolution in $21^{\text {st }}$ Century", on L. Franklin Elmore, (eds), (2013), Fundamental of Construction Law, $2^{\text {nd }}$ Edition, United States of America: ABA Publishing, 2013, p349.

2 Gail S Kelley, Construction Law: An Introduction for Engineers, Architects, and Contractors, Canada: John Wiley \& Sons, Inc. 2016, p51.

3 Joseph T. A.B Bockrath, Contract and the Legal Environment for Engineers and Architects, Sixth Edition, United States: Mc. Graw Hill, 2000, p68-69.

4 Note 3, p73. incorrect application of construction method or any suspension order to the project resulted by serious accident. The increasingly complex nature of modern construction projects and the competition among the contractor results in the propagation of construction dispute. No proper management of construction dispute will rise up the frustration levels to the parties among the construction project. ${ }^{5}$ The dispute will then become a barrier and obstruct the construction progress even the construction contract failure while the settlement method is absent or present in wrong timing. And this 'barrier' will proliferate uncomfortable emotion among the project and ultimately results in the project failure.

Disputes in construction project sometimes inevitable although the parties stated carefully all the project requirement in their contract. ${ }^{6}$ To anticipate the future disputes arise, the parties also drafting disputes settlement clause. They want a dispute resolution mechanism which is fast, effective and efficient to settle the problems. In fact, there are several methods in settling the construction disputes. The most common process to resolve disputes is through litigation, but generally, the process of dispute resolution through courts lasts for decades,

5 See, Disputes Resolution Technique in construction. (2003). Available online from https://www.lawteacher.net/free-lawessays/contract-law/dispute-resolutionstechnique-in-construction-contract-lawessay.php (retrieved June 4, 2017).

6 The other causes of contract disputes are usually using the standard contract which is not suitable for the parties by any reasons, or the contract which is sometimes set only by one parties and it's considered unbalance for the other parties. See Yuanitasari, Deviana, 2017, "The Role of Public Notary in Providing Legal Protection on Standard Contracts for Indonesian Customer," Sriwijaya Law Review, 1 (2), p181. 
and not to mention the wasted costs, mind, and energy. ${ }^{7}$ Judicial proceedings through courts are sometimes only formalistic because the parties to the dispute are forced to accept the judgment of the court, even though the verdict itself is deemed not to satisfy the sense of justice.

In the other hand, there are many alternative dispute mechanisms that should be considered by the parties, because in each method have its own advantages and disadvantages. For instance, mediation or conciliation is really depended on the mediator skills and the good faith of the parties. Other alternative dispute resolution such as arbitration that prioritizes speed, professional and fix cost also has its own problems and questioning by the parties. ${ }^{8}$ Therefore it's interesting to examine, how the parties select the best alternative disputes settlement mechanism to settle their disputes? And how it should be drafted in their construction contract?

\section{RESEARCH METHODS}

To answer the problems above, the method used is normative legal research. The objective of this research was to understand clearly and holistically the complexities of construction disputes mechanism. It will be the core analysis regarding the development of the settlement disputes, as well as in selecting and drafting its provision.

This research was conducted in two stages: (1) identification of problem background, literary study, (2) collection of

Indonesian New Regulation No. 2 Year 2017 on Construction Activity stipulated that arbitration is the mechanism chosen by the parties to settle their disputes is negotiation fails in the first step.

8 Baker Ellis (et.al), Fidic Contracts: Law and Practice, London: Informa, 2000, p505. normative data through field observation as well as gathering data and information. This study used legal materials which consist of primary, secondary and tertiary research materials. (3) To obtain comprehensive legal conclusion, this study employs statute and comparative approach. (4) The data is analysed by using descriptive qualitative to answer the above problems. ${ }^{9}$

\section{ANALYSIS AND DISCUSSION Selecting Settlement of Construction Contract Disputes Construction Disputes}

Construction disputes often occur mainly because activities in the field of construction are indeed full of risks. This dispute occurs when either party considers that the other party has committed a breach of its obligations ${ }^{10}$ and responsibilities. ${ }^{11}$

Another frequent source of disputes is the question of which party is responsible for the correctness and completeness of documents, data, and information that form part of the construction contract. Especially in large projects tenderers often receive comprehensive technical and other background information on the project which finds its way into the contract documents and serves as the basis of the contractor's performance (e.g., preliminary design works, feasibility studies, ground surveys, environmental conditions etc.). The parties

9 Peter Mahmud Marzuki, Penelitian Hukum, Second Edition, Jakarta: Prenada Media Grup, 2006, pp141-143.

10 Seng Hansen, Construction Contract Management, Jakarta: PT. Gramedia Pustaka Utama, 2015, p218;

11 The requirement of responsibility is any damage or loss as a result of an unlawful act. Nurhidayatuloh, et al., 2018, "Forsaking Equality: Examine Indonesia's State Responsibility on Polygamy to the Marriage Rights in CEDAW," Jurnal Dinamika Hukum, 18 (2), p192. 
are free to determine to what extent the employer is liable for information provided to the contractor and to what extent the contractor ought to have reviewed and discovered inconsistencies or is even deemed to be satisfied with the quality of such information. In the absence of a precise agreement to that effect there often is significant room for argument on both sides. Liability for unknown conditions such as ground conditions is often determined by reference to a benchmark of conditions an experienced contractor acting with due skill and care would have identified requiring expert evidence to establish such standards. ${ }^{12}$

The construction contract has a complete aspect as mentioned by Nazarkhan Yasin, it consists of technical aspect, law, administrative, finance, tax, social economic and environment. Sometimes law aspect is not considered as a potential conflict in future. The aspects which mostly become the causes of the disputes are suspension of work, termination of contract, liquidity damages, settlement of disputes, force majeure, governing law, contract language, domicile of the object and the parties. ${ }^{13}$

Project management Body of Knowledge (PMBOK) mentioned that the causes of construction disputes are an internal risk and external risk. The internal risk is things that the project team can control or influence, such as staff assignments and cost estimates. External risk is things beyond the control or influence team, such as mar-

12 Jenkins Jane, International Construction Arbitration Law, Second Revised Edition, Netherlands: Kluwer Law International BV, 2013.

13 Nazarkhan Yasin, Mengenal Klaim Konstruksi di Indonesia dan Penyelesaian Sengketa Kontruksi, Jakarta: Gramedia Pustaka Utama, 2003, p85. ket shifts or government actions. ${ }^{14}$ There are also risk sources in the contract itself such as incomplete contract clause and its interpretation, change order and claim, guaranty and warranty, patent right and force majeure.

It is also not uncommon to find that a construction contract is internally inconsistent or ambiguous and, in the absence of a well-drafted precedence clause, disputes frequently involve resolution of competing clauses. For example, a common problem is where a technical specification prepared early in the life of a project by a consultant engineer contains substantive clauses that contradict the conditions of contract prepared much later, based on a standard form or by a lawyer who is never shown the technical specification. Another is where the specification envisages procedures for design development that are inconsistent with the conditions of the contract. Of course, such inconsistencies should ideally be addressed and removed or reconciled before the contract is executed. Best practice is for lawyers to work with the technical experts, project managers, and contract administrators to ensure the schedules and terms and conditions are compatible and reflect procedures which are practical and workable for the supervision and management of the works. Experience tells that this practice is not uniformly adopted and hence disputes arise during project execution and thereafter were liabilities of the parties have to be addressed by reference to competing provisions. ${ }^{15}$

14 PMBOK Guide, A guide to Project Management Body of Knowledge, Fourth Edition, Pennsylvania: Project Management Institute Inc, 2008, p275.

15 Jane Jenkins, Note 10, p14. 
Where disputes are concerned, prevention is much better than cure. Employers should decide what they want and designers, contractors, sub-contractors, and suppliers should ensure that they understand what is expected of them. Parties should then enter into proper contracts and not rely on letters of intent or other nebulous arrangements. ${ }^{16}$ Legal disputes in construction agreements may happen in precontractual, during construction; and postcontractual which occurs after the work is completed and after Final Handling over (FHO). ${ }^{17}$

Legal disputes in construction contract can be caused also by the choice of dispute resolution itself. The absence of the choice will cause the length of disputes settlement. Sometimes, if the problems have arisen, but the method in settling disputes hasn't decided or concluded by the parties, then it's become the first dispute that should be settled. Mostly, disputes in a construction agreement can be resolved through several options, like Alternative Dispute Resolution by negotiation, mediation, conciliation and expert opinion. If not resolved then the next option is the choice of settlement through Court, or Arbitration either Institution or Ad Hoc. Currently, some methods are also developed by some institutions.

\section{Selecting the Best Alternative Mechanism in Settling Construction Disputes}

There are many form contract provided for some kinds of mechanism of disputes resolution without making a judgment as to

16 John Newey, "Construction Industry," in Peter Fenn and Rod Gameson (Ed), Construction Conflict Management and Resolution, 1992, pp20-25.

17 Suntana S Djatnika, 2017, "Disputes in Construction Contract," BANI Arbitration Quarterly Newsletter, Vol. 9. whether particular form is appropriate. The owner may want to retain the right to determine which claims are mediated or arbitrated and which are litigated. ${ }^{18}$ Although currently the industry has taken steps to avoid litigation by developing various mechanisms for Alternative Dispute Resolution (ADR) that can be used during nearly any stage of a construction project. ${ }^{19}$ The used of ADR techniques ranges from simple negotiation to binding arbitration. The construction industry has essentially revolted against long, complex, expensive court trials of complicated and factually intense and difficult construction cases. ${ }^{20}$ At least there are generally five steps for resolving disputes. The first two deal with contract provisions: equitable allocation of responsibilities and risks and procedures for dealing with contract disputes. The third step involves team building (such as partnering) and establishing objectives. Step four provides a neutral forum to resolve disputes throughout the life of a project. Techniques include Dispute Review Boards, mediation, rent judge programs and mini-trials. Step

18 Bruner L Philip, Introduction, In Elmore 1, Franklin, et.al (ed), Fundamentals of Construction Law $2^{\text {nd }}$ Edition, United States of America: American Bar Association Publishing, 2013, pp12-13.

19 Both the Industry and environment conflicts seem to avoid the settlement disputes through court or many reasons therefore ADR is developed currently. Achmad Romsan, et al., 2017, "Climate Change and Community Environmental Conflicts: Are They Correlated?" Sriwijaya Law Review, 1 (1), p54.

20 This has happened in the United States while the industry has embraced a number of alternative dispute resolution techniques which have revolutionized the dispute resolution process in the United States construction industry, See Dennis Campbell, Structuring International Contract, London: Kluwer Law International, 1996, pp160-167. 
fifth; the "last resort" is binding ADR, such as arbitration.

In international law, ADR Methods also stipulated in Article 33(1) of the Charter of the United Nations which provide sufficient complete guidance for the parties to the dispute within the scope of international law including international construction contracts. "The parties to any dispute shall seek a solution by negotiation, inquiry, mediation, conciliation, arbitration, judicial settlement, resorting arrangements or other peaceful means of their own choice." ${ }^{21}$ Den Haag Convention 1965 and UNCITRAL Model Law also mentioned that parties undertake to submit their disputes in any forum they may choose.

In general practice, the method of dispute resolution chosen by the parties is a peaceful forum like, negotiation, mediation, and arbitration, which sometimes mention as traditional ADR method. All of the methods have their own strengths and weaknesses. Then it is important to elaborate further each method and the Development of ADR Techniques in constructions disputes settlement.

\section{Negotiation}

Negotiation is a voluntary process that can occur at any time after a dispute arises, up to and including while the dispute is pending before the appellate courts. Traditional negotiations take place without the assistance of third parties and can involve as many or as few people as needed to reach a resolution. Kohona mentions that negotiation is an efficacious means of settling disputes relating to an agreement because they

21 Achmad Romsan, Alternative Penyelesaian Konflik. Malang: Intrans Publishing, 2016, pp3-5. enable parties to arrive at conclusions having regard to the wishes of all disputants. ${ }^{22}$

In this case, Construction negotiations are frequently more complex because they may affect the rights of more than two parties. The strength of negotiation is the importance of preparing for the negotiation and thoughtfully considering the objectives to be achieved. Also crucial is the selection of a negotiator with the skills to reach the agreement and the knowledge and willingness to deal reasonably with important points as they arise. Finally, any negotiated agreement should be put in writing immediately to create a binding document reflecting the agreed-upon terms while they are still fresh in the minds of the negotiators. $^{23}$

Negotiation is also the method used by the parties before choosing other dispute resolutions. Negotiation is an effective way in which the parties resolve the disputes without the intervention of a third party. The positive side of this method is that the parties as the decision maker, the case is confidential and other advantages are that there is no formality in this method and the cost is cheap. However, besides the positive aspect of this method, there is a negative aspect which should be considered by the parties, that the effect of the deal in negotiations is based on the good faith and the will of the parties. When the party's position is unbalanced, then the negotiation process may be interrupted. The effectiveness of this method depends on the commitment of the parties. ${ }^{24}$

22 Meria Utama, Hukum Ekonomi Internasional. Jakarta: Fikahati Aneska, 2012, p57.

23 Alan E Haris, Note 1, p353.

24 Huala Adolf, Dasar-dasar Hukum kontrak Internasional, Revision Edition, Bandung: Rafika Aditama, 2008, p203-205. 


\section{Mediation}

One of alternative disputes settlement is mediation. It is a non-binding form of negotiation employing the assistance of a third party (the mediator). The mediator should be neutral and impartial. ${ }^{25}$ Although it is increasingly common for contracts to squire mediation as a precondition to starting a binding form of dispute resolution such as arbitration or litigation, most mediation follow the voluntary agreement of the parties to use this form of ADR.

Black's Law dictionary give the definition of mediation "intervention; interposition; the act of a third person in intermediating two contending parties with a view persuading them to adjust or settle their dispute. Settlement of dispute should involve a neutral party." ${ }^{26}$ The first key step to establish a successful mediation is selection of the mediator. Characteristics of mediator must be considered by both parties. Many researches have been written on whether to select a mediator who "facilitates" a resolution or who "evaluates" the dispute. The successful mediator must have both abilities as a mediator and a facilitator. Gary Goodpaster ${ }^{27}$ explained that the role of mediator is to analyse and diagnose the disputes and control the process of mediation to guide the parties reach agreement. A number of countries which are popular us-

25 Sudiarto, Negosiasi, mediasi, dan Arbitrase, Penyelesaian Sengketa Alternative Indonesia. Bandung: Pustaka Reka Cipta, 2015, pp36-37.

26 Black's Law Dictionary, $5^{\text {th. }}$. Ed, 1979, p885.

27 Goodpaster Gary, Settlement Disputes In Fundamental of Arbitration Economic in Indonesia, Jakarta: Penerbit Ghalia Indonesia, 1995, pp16-17. ing this method is Japan and China and others country as well. ${ }^{28}$

The mediator does not decide who has the correct positions or how much money should be exchanged to resolve the dispute. The mediator's role is to make sure that the parties understand each other's positions, that they have their theories tested by probing questions from the mediator, and that they fully understand the risks and costs of proceeding to the next step in the dispute solution process. Therefore mediator must have some skills which are used to bring the parties to an agreement is far more important. A good mediator is flexible, suit in any situation comfort to the parties. ${ }^{29}$ If the situation is deadlock, the mediator can choose which parties could come to the mediation process, since the decision maker on behalf of the company should attend, so the result of mediation can be applied. While the mediator does not judge the merits of the case, a good mediator is much more than a messenger carrying offers from one group to another. An effective mediator will ask questions tough, express scepticism of position when it is appropriate, advice to the parties on the possibility that their position will assist or detract the settlement process. ${ }^{30}$

In fact, a good mediation process finally is related to mediator skill and the good faith of the parties when they reach the agreement, then it is important that the agreement is in written and signed by the parties or necessary offices. Without good faith and written agreement, the mediation process is ineffective and useless.

28 Adi Nugroho, Susanti, Mediasi, Sebagai Alternative penyelesaian Sengketa. Jakarta: PT. Telaga Ilmu Indonesia, 2009, pp58-59.

29 Note 25, p65.

30 Alan E Harris, Note 1, pp354-355. 


\section{Conciliation}

A method of settlement disputes is set up by the parties either on permanent basis or ad hoc basis deal to the disputes. ${ }^{31}$ One of the common methods is conciliation, which has been used to resolve disputes on questions of law, the relevant facts, or a combination of both. It can be utilized in the settlement disputes involved "non-arbitrable" or "non-justiciable" issues and is generally not hindered by jurisdictional challenges. ${ }^{32}$ Conciliation is used, even when there are relevant sources of law that can be applied, because the disputants may wish to soften the impact of the legal principles concerned by implementing a conciliatory approach that focuses on reaching an equitable solution. Conciliators are given flexibility in the pursuit of a just result and, although certain laws and sources of obligation cannot be disregarded, extant conciliation rules reflect this relative freedom. ${ }^{33}$

Although conciliation has been used in some domestic societies for hundreds of years, the concept of conciliation resembles mediation, with both methods using a third party to facilitate a non-binding result through the medium of communication with the disputants. Indeed, the two terms mediation and conciliation are occasionally used interchangeably. In the transnational system, a distinction between the two can be made in the degree of formality and lev-

31 J.G. Merrils, International Disputes settlement, Third Edition, United Kingdom: Cambridge University Press, 1998, pp62-63.

32 Priyatna Abdurrasyid, Arbitrase dan Alternative Penyelesaian Sengketa, An Introduction. Jakarta: Fikahati Aneska, 2002, p54.

33 Richard Gwynne and Stephenson Harwood, "Governing Law and Disputes Resolution" on Dennis Campbell (Ed), Structuring International Contract, London: Kluwer Law International, 1996, pp275-278. el of initiative imposed on the third party. Compare to conciliation, mediation is more informal. Conciliation, on the other hand, is more formal in structure and procedure, yet retains a non-adversarial environment. The central objective of the conciliator is to facilitate an amicable settlement of the conflict by communicating with the parties, typically through structured conciliation proceedings, and by submitting written proposals for a resolution of the dispute. ${ }^{34}$

The result of conciliation is the nonbinding character of the conciliator's recommendations. The actual recommendations are not binding on the disputants because they are ultimately free to accept or reject the recommendations, therefore this method sometimes does not use by the parties. However, there is some procedure like ICE Conciliation Procedure 1994 clause 66, which ask conciliator as the mediator, if an agreed settlement is not achieved, the conciliator may give a recommendation which may become binding upon the parties if a notice to refer to arbitration is not given. ${ }^{35}$ This rule is quite strange, but if it is agreed otherwise by the parties, then it is applicable.

\section{Neutral Forum}

This method means that it is a neutral mechanism allowing parties to solve their disputes outside of court in a private forum, with the assistance of a qualified neutral intermediary of their choice. ADR can only be applied if all parties agree to submit their dispute to the procedure or if it is

\footnotetext{
Joseph T Bockrath, Note 3, p500.

35 U.N. Doc. A/CN.9/180. Note 17, p6; UNCITRAL Conciliation Rules. Note 18, Art. 13(3); ICC Conciliation Rules. Note 18, Art. 7(a), The parties may include an arbitration clause in the settlement agreement in the event of a dispute over its enforcement.
} 
mandated by a competent court. The benefits of this choice include time and cost efficiency, flexibility, party control, neutrality, a single procedure, confidentiality, and expertise. Some institution such as WIPO Arbitration and Mediation Centre offers this mechanism.

\section{Arbitration}

One popular method and mostly used in construction standard contract are using an arbitration. The term of Arbitration means that it is an alternative dispute resolution which is the submission of a dispute to a disinterested person or persons for the final decision. ${ }^{36}$ An arbitrator is selected by the disputants. If the parties are not willing or able to appoint an arbitrator when the time comes to do so, a court can make the appointment, but such an appointment is based upon prior agreement of the parties to arbitrate.

Most cases which are brought to arbitration are an impact of parties' agreement in advance by inserting an arbitration clause in their contract. The agreement of the party can be put in the arbitration clause, or in submission arbitration agreement. Therefore, there is no arbitration without arbitration agreement. ${ }^{37}$ There are number perceived advantages of arbitration as means of settling disputes between parties to international contracts, these include $^{38}$ 1) The speed of efficiency and possibly lower cost as a result; flexibility (for example, the ability to choose a technically qualified arbitrator to determine technical disputes); 2) Privacy, since arbitration is a confidential method; 3) The parties can

36 Priyatna Abdurrasyid, Note 29.

37 Huala Adolf, Note 21, p197

38 Gwynne, Richard, and Harwood, Stephenson. Note 32. choose the forum and select the tribunal and where the parties are not obviously submitting to the jurisdictions of the courts of particular countries; and 4) Enforceability in the countries member of New York Convention.

Arbitration may be resorted to even while work under the contract is progressing. Utilization of this medium avoids both the costs of litigation and the delays resulting from crowded court dockets. Because it can proceed with relative speed, the arbitration procedure is especially beneficial if the dispute is such that it has caused or may cause performance under the contract to be suspended pending a settlement. In that situation, the arbitrator should be authorized to direct that work under the contract is to continue during the arbitration process if such an order is in the best interest of the project. ${ }^{39}$ The common method that adopted by the parties and considered as the basis of the arbitration process is the UNCITRAL Model law which is established by United Nation Committee of International Trade. This settlement method only applied if the parties stated explicitly in their contract. ${ }^{40}$ Every country nowadays has its own arbitration centre.

It is quite possible that arbitration will be needed to settle disagreements that materialize after the performance of some portion of the work but prior to final winding up of accounts. It may also happen that disputes arising during construction are held to be resolved subsequently. For example, a contractor was making a large excavation strictly accordingly to the plans. One side

39 Joseph T Bockrath, Note 31, pp491-492.

40 Ahmadi Miru, Hukum Kontrak dan Perancangan Kontrak Jakarta: PT. Raja Grafindo Persada, 2007, p114. 
of the cut caved in and caused serious settlement of some adjoining construction. The engineer and the contractor agreed that the latter should take immediate remedial steps to save the structure, keeping account of all expenses involved. They agreed that the question of responsibility for the failure and thus the question of which side must assume the cost was to be settled by arbitration later on. ${ }^{41}$

The arbitrator customarily resolves disputes involving such matters as: 1) what is or is not included in the contract, 2) the proper interpretation of drawings and specifications, 3) the extent of monetary adjustment for mistakes made and poor workmanship performed by the contractor, 4) claims for liquidated damages, 5) determination of the computed quantities to which the bid unit prices are to be applied, 6) claims for delays, and 7) extras and allowances. ${ }^{42}$

Those are five traditional ADR methods which already popular and mostly used by the parties. Some experts in construction disputes resolutions give advice in selecting the appropriate mechanism to settle their disputes. The forum shopping is one of the ways to know the advantages and disadvantages of every mechanism related to their project. For instance Stokes who provides some alternative recommendations for the settlement of construction disputes by using the traditional ADR method for example by conciliating firstly with the parties with construction experts or construc-

\footnotetext{
41 Cheung, Sai-On, 1999, "Critical Factors Affecting The Use Of Alternative Dispute Resolution Processes in Construction. "International Journal of Project Management, 17 (3), pp189-194.

42 Joseph T Bocrath, Note 36, p494.
}

tion associations, even though stocks doubt the effectiveness of this conciliation because it is often bye by the Parties themselves, therefore he offer another recommendation is to involve the engineers or experts in the field of construction to be a mediator or arbitrator. That can be formed through ad-hoc arbitration.

However, on book review on the construction contract, Robert Coulson criticized that arbitration is indeed much chosen by the parties in the settlement of construction disputes, but often the mechanism is surpassed by the parties themselves. For an instant, in the case of the appointment of the arbitrator, each of the parties appoints the arbitrator to which they have agreed, but when required to agree to appoint a third arbitrator, it's become so difficult to agree upon, even appeal the right to a court. He further disagrees with McNeil stokes ${ }^{43}$ who argue that one alternative dispute resolution is to make ad-hoc arbitration which is the arbiter is an expert in the field of construction, according to Robert Coulson it is even more dangerous if the choice of dispute resolution by the parties using arbitration ad-hoc due to unclear about the rules and procedures that will be in agreement. ${ }^{44}$

For there are some weakness in some dispute resolutions method, therefore some institution introduce the new strategic approach to dispute prevention and resolutions as above mentioned, such as:

1. On-Site ADR techniques by using partnering as an attempt to have the principal parties in a construction project

43 McNeil Stokes, Construction Contract, Second Edition, New York: McGraw Hill, p126.

44 Robert Coulson, 1980, "Book Review on Construction Contract by McNeil Stokes", Arbitration Journal, 36 (3), pp170-198. 
agree on common goals before construction begins. This method developed in the United States and other countries which do some megastructure. This method is the result of the communication failure among the parties and creates disputes. These parties meet, usually with the facilitator for a day or more. Normally this method involves key representatives of the owner, general contractor, major subcontractors, designers, and others who will have a significant influence on the project. This is one of the few opportunities where parties not in contract with each other (for example, owners and subcontractors; contractors and designers) address each other and deal with important issues. Successful partnering requires the involvement of field and home office management who have the power in decision making. The result of a successful partnering session is projected charter which is the creation of the parties involved and signed by all participants.

2. Disputes Review Board; Dispute Adjudication Board (DAB) consisting of neutral experts who will visit the site. Periodically in order to monitor the progress and potential problems. DAB is an informal process which encourages party involvement and recognizes the need for speed. A DAB can be created at the start of the project or when a dispute occurs. It has one or three members with the default are three members, in which each party nominates one member for approval of others and the parties agree on third who acts as chairman. If the contract contains a list, members are selected from that list, unless unwilling/ unable to act. Each party may appoint a replacement member at any time and pays half of the cost. $^{45}$ Depending upon the DRB's charter, its decision may be advisory or binding. This method is developed by FIDIC and currently used by contracting parties to settle their disputes.

3. Mini-Trials; This kind of trial are more structural form than mediation. A facilitator such as mediator is used; presentations are made to the facilitator and frequently to key decision makers of the parties as well; and private negotiation sessions are used after the presentations to negotiate resolutions. The procedures are flexible and can be tailored to the particular disputes although sometimes more formal than mediation. For instance, the parties may elect to have a mini-trial on one or two key issues in a larger dispute. A mini-trial is more formal than mediation in several respects. In the United States mini-trials is part of ADR for resolving a legal dispute from a formal court trial. Mini-trials, like mediations and arbitration, constitute unique forms of "alternative dispute resolution" (ADR) favoured by courts and litigants alike. There has been a general increase in all forms of ADR in recent years because of the advantages offered: reduced cost, fast resolution, privacy, and less adversity in effect. A mini-trial is really not a trial at all. Rather, it is a settlement process in which the parties present highly summarized versions of their respective cases to a

\footnotetext{
Majedi Hasan, Dispute Resolution Mechanism under FIDIC Form Of Contract, BANI Indonesia Quarterly Newsletter, Vol.6, December 2014, p12.
} 
panel of officials who represent each party (plus a "neutral" official) and who have authority to settle the dispute. The presentation generally takes place outside of the courtroom, in a private forum. If the parties desire, may actually render written, advisory decision about the merits of the disputes. The mediator then may offer opinions regarding the merits of the cases; may make predictions of how a judge, jury, or arbitrator would resolve the dispute; and, if the parties' desire requires, may actually render a written, an advisory decision about the merits of the dispute. This method sometimes saves a substantial amount of money over the next steps of dispute resolutions. ${ }^{46}$

4. Hybrid techniques; is a combination of mediation and arbitrations. It is hoped that by using this method, the weakness of mediation and arbitration can be eliminated. The difficulty is that finding a qualified person with all attributed. A person who understand construction, having mediation and also arbitration skills.

In determining which methods of dispute resolution procedures may be suitable for a particular project will depend on a number of factors, including: 1) the size of the project from a monetary perspective; 2) the scope and expected duration of the project; 3) the jurisdictions in which the parties are based; 4) the location of the project; 5) whether the parties have an existing (or developing) long-term, ongoing relationship; and 6) Whether there are multiple parties (e.g., subcontractors, lenders) and/or multiple agreements involved in the project.

46 Alan E. Harris, Note 27, p357-358.
Therefore generally the decision of the parties in choosing the settlement of disputes based on the problem itself, the cost and the commitment of the parties. Then it is the autonomy of the parties to choose the best settlement for their disputes. The other principal used as the base of the parties' decision is predictability and effective principal. If the problem is not complicated one, then negotiation or partnering can be used. In the situation where the disputes more complicated, and the first step of approach has been done, then the Disputes Settlement Bodies or mediation is the best alternative. While the parties' commitment is in question in complicated disputes, then arbitration or hybrid mediation is the best alternative, although the cost in these methods should be calculated. Unless the contract clarifies the maters, a question may arise about who should pay the cost of the chosen dispute settlement method. The visible expenses (for attorneys, expert witness, and dispute resolution process) are significant. The less visible costs (e.g. company resources assigned to the dispute, lost business opportunities) and the intangible costs (damaged business relationship, inefficient dispute process) are also considerable, although they are difficult to quantify. Because of the cost-effectiveness and time to resolve the disputes are critical factors, FIDIC, for instance, has introduced a strategic approach to dispute prevention and resolution that employs a neutral advisor, early intervention and the ability to tailor the resolution method to the particular nature of the dispute. Therefore while the parties make an agreement to choose one method to settle their dispute the all aspect must be reconsidered. Things that should be considered are that ADR will often prove 
more successful at the start of a project than at the end, when there may be no ongoing commercial connection or the prospect of an ongoing relationship. It is essential to recognize the procedure and the outcome of that process.

In accordance with international construction contract disputes, Edwin H. W. Chan1 and Raymond Y. C. Tse states that disputes in the field of construction, although included within the scope of international disputes, should take account of the legal culture of the state of the parties involved, its related to the considering of chosen based on the location of the project. ${ }^{47}$ Arbitration is one of the mechanisms of dispute resolution that can be elected by the parties. However, they explain that "to interact with such a legal culture, traditional arbitration practices have to be modified to incorporate a proactive, flexible, and amicable "no adversarial process" needs a modification of the arbitration itself specifically to the construction dispute. Fenn, et al, also says that "In addition to the traditionally adapted arbitration, many new ADR mechanisms, such as mediation, an executive tribunal, adjudication, a dispute resolution advisor, and a dispute review board, have been developed" Where the development of construction disputes is also developing, countries that continue to develop this mechanism, for example, is the country of Hong Kong and England. ${ }^{48}$

Fellow RF and Hancock R explain that international construction disputes are in-

47 Edwin h. W. Chan and Raymond Y. C. Tse, "Cultural Consideration in International Contract", Journal of construction engineering and management, 2003, p375.

48 Fenn, P., (et.al), Dispute resolution and management in construction: An international review, London: E\&FN Spon, 1998, pp198-202. separable from the customs of a country, so construction contracts involving parties from different countries often experience disputes or differences of opinion in interpreting the contracts they make. ${ }^{49}$

The development in construction disputes settlement mechanism become an alternative which interesting to consider the parties. Some countries have anticipated these kinds of the method such as United Kingdom, Australia, Singapore, New Zealand, Malaysia and Indonesia. ${ }^{50}$ On the Other Hand, some Institution like FIDIC, JCT, SIA, as a fast and responsive organization and very popular in construction world offer also partnering, Disputes Review Board and Disputes Adjudication Board to settled even to anticipate the disputes. 51

\section{The Drafting of Disputes Settlement Pro- vision in Construction Contract.}

Why are dispute resolution provisions important? This is not a rhetorical question Parties frequently spend significantly less time and effort drafting and negotiating the dispute resolution provisions in their contracts than they do on the commercial and financial terms. Such provisions are often found towards the end of the contract. Parties sometimes simply use boilerplate dis-

49 Fellow, R. F., and Hancock, R "Conflict resulting from cultural differentiation: An investigation of the new engineering contract", Rotterdam: Council of International Construction Research and Documentation Proc. on Construction Conflict: Management and Resolution, 1994, pp259-267.

50 For Instance in Malaysia, The adjudication has stipulated in their regulations, See, Nicholas Gould, "Adjudication" at http://www.fenwickelliot.co.uk/, p1.

51 Majedi Hasan, Dispute Resolution Mechanism under FIDIC Form of Contract, BANI Indonesia Quarterly Newsletter, 2014, 6 (12). 
pute provisions or precedent language from another contract, without considering whether that language is appropriate for the agreement/project in question. In other cases, they may fail altogether to include dispute resolution provisions in their contract.

A lack of attention to dispute resolution provisions may be caused by a variety of factors, including a reluctance by the parties to acknowledge that problems might arise in their relationship in the future and/or pressure to finalize the negotiations and execute the contract, which may prevent parties from undertaking a considered review and analysis of what type of dispute resolution provisions would be most appropriate for the contract/project in question and whether decisions will be capable of enforcement against available assets.

Whatever the reason, a party may find that it is seriously disadvantaged as a result of having spent little (or no) time when the contract was prepared to address the appropriateness of the dispute provisions. This is particularly true if the contract is international in nature, as a party may find itself exposed to disputes being resolved in the local courts of foreign jurisdictions. The laws and procedures of that jurisdiction may be very different from those the party is familiar with or would wish to apply to its dispute. $^{52}$

The disputes settlement provision is one important part of the construction contract. The result of forum shopping is the party's decision on what method they are going to use if the dispute arises. The choice mostly stated in construction contract dispute settlement clause. Then the next step is drafted carefully the choice in

52 Jenkins Jane, Note 10, p49. their disputes settlement provision. Drafting of construction contract documentation is no easy task and typically involves the inclusion of provisions for anticipatory contingencies. ${ }^{53}$

There are two methods in drafting the clause,

1. Tailor Made clause, where the parties deal to create a clause regarding to settlement disputes. In this case the drafter stiffs for clarity and precisions, goals which are frustrated by vague and ambiguous language. Vagueness is a matter of degree, a shading of meaning. Ambiguity is a matter of choice among different connotations; the meaning must be one thing or another. ${ }^{54}$ These two items must be avoided in the contract because it can create problems.

The reason why the parties want to draft their own clause is the cost of the mechanism in settlement disputes organization. Some organization for instant FIDIC and JCT stipulated that the parties who use their template or standard contract must pay a certain amount of money. Therefore, based on the autonomy of the parties theory that allowed them to make their own contract clause, then tailor-made clause is the best option, One of International Contract sources is UNIDROIT Prin-

53 Sai-on Cheung, 1998, "Critical factors affecting The Use of Alternative Disputes Resolution Process in Construction", International Journal of Project management, 17 (3).

54 Burham, J. Scott, Drafting Contract, the Second Edition, United States of America: Michi Company, 1993, p95. 
ciples that harmonized sets of rules on constructions clauses. ${ }^{55}$

These things should consider while the parties or the contract drafters on behalf of the parties want to draft their own clause, namely: 1) the parties must be really carefully drafted their disputes settlement choice. It must be clear and simple, plain English is suggested ${ }^{56}{ }^{2}$ ) selecting the rules chosen in the mechanism of settlement disputes; 3 ) selecting the forum will be ad hoc or under some institution; 4) stipulated the governing law; 5) the Panel's Power; 6) considering the mechanism of interim measures; 7) confidentiality; and 8) Timescale to provide the decision.

Actually, there are many drafter checklists if the parties want to draft their own clause. There are many issues that need to take into account for use in the international construction contract. Parties can provide their own rules concerning the selection of neutral party and conduct ADR Procedure. Indeed, many companies while doing their project have their own bespoke ADR procedures, which are introduced into their contract as the first stage of the disputes resolution process, sometimes with an option to leapfrog straight to litigation or arbitration if

55 The objective of UNIDROID Principles is to establish a balance sets of rules designed for use throughout the world irrespective of legal traditions and the economic and political conditions of the countries in which they are applied, Adolf, Huala. Some Fundamental in International Contract Law, Bandung: Refika Aditama, 2010, pp97-98.

56 Kusumadara, Afifah, International Business Contract, Jakarta: Sinar Grafika, 2013, pp15-16. both parties agree that their ADR is not appropriate. ${ }^{57}$

2. The simple's way in drafting disputes mechanism settlement clause is using the standard form of settlement disputes organizations. The parties may decide to adopt existing provision such as those that have been developed by some Institutions like FIDIC, Joint Contract Tribunal (JCT), American Arbitration Association (AAA standard charter), BANI (Arbitration Centre Indonesia), Singapore International Arbitration Centre (SIAC), Singapore Institute of Architect (SIA), International Chamber of Commerce (ICC), Ice Mediation standard etcetera.

The Benefits of adopting standard clauses are: 1) the clause is drafted professionally and based on experiences; 2) it gives comprehensive guidelines. All considerations in drafting such clauses as mention above usually have been anticipated by these organizations; 3) there are securities and guarantees of procedure and result; 4) ones the parties adopting, it means that it eliminated the time-consuming in negotiations and drafting the clause, for it is already provided in the standard contract form.

The contract drafter, however, are reminded that sometimes the standard form is protected by copyright and trademark, therefore in adopting the clause must have specific written consent, the parties must have the license to adopt the clause, for instant in FIDIC Contract Guide, the parties are bound on some flow chart procedure and of course this has a cost to pay. ${ }^{58}$

\footnotetext{
Jane Jenkins, Note 10, pp56-64.

58 FIDIC Conditions of Contract for design, Build and Operate Projects, general Conditions
} 
Therefore it depends on the parties' choices whether would like to adopt standard contract or to be drafted by themselves. The most important factor is that ADR will success if the consent of the parties to settle the disputes peacefully and respect to the result. It is better than the mechanism also maintain long-term and the future relationship between the parties.

\section{CONCLUSION}

The complexity, long-term, many parties involved and complicated design of construction contracts, and greater the nominal amount of construction contracts sometimes make the disputes are inevitable. Therefore, the parties should find the best alternative mechanism to solve the problems otherwise the performance of the contract may be the failure. There is some mechanism can be selected by the parties. As mentioned above that the increased use of ADR in construction disputes has occurred as owners, contractors, subcontractors, designers, and sureties have turned away from the court system to resolve their disputes. On the other hand, slowly the perception of the advantages of ADR is changing. Although there are some strengths and weaknesses of every method, currently mediation and arbitration are still the most common forms of alternative dispute resolution selected by the parties.

The ADR developed in many ways to anticipate those weaknesses. There are a number of other methods create by some institution include the hybrid mediation and arbitration, mini-trials, summary jury trials, and dispute resolution boards or disputes adjudication boards. As well as some insti-

particular conditions and Sample Form, First Edition, 2008. tution offering some disputes resolution, the parties need to select carefully each method proposed. There are at some consideration of parties in selecting the mechanism such as the size of the project, scope of the project, the location of the project, the seat and jurisdictions of the parties, the scope of the problems, commitment and future relationship of the parties.

Furthermore, after they choose the method, then the parties must be stipulated the construction disputes mechanism carefully in their construction contract. The provision mostly stated in the main contract and it can be drafted based on the standard form of one institution or can be tailormade drafted by the parties. While using the standard forms it means that both parties agree on the rule and procedure of the institutions. On the other hand, if the parties want to draft by themselves, then at least the mechanism, law governs the disputes and the jurisdiction must be stipulated clearly, otherwise this may create other disputes in future and make the main problems hard to be settled.

\section{REFERENCES}

\section{Books}

Abdurrasyid, Priyatna. 2002. Arbitrase dan Alternative penyelesaian Sengketa, Suatu Pengantar. Jakarta: Fikahati Aneska.

Adolf, Huala. 2010. Dasar-Dasar Hukum Kontrak Internasional. Bandung : Refika Aditama.

Baker, Ellis (et.al). 2000. FIDIC CONTRACTS: Law and Practice. London: Informa.

Black's Law Dictionary, 5th. .Ed.1979.

Bockrath, Joseph T. A.B. 2000. Contract and the Legal Environment for Engineers 
and Architects, Sixth Edition, United States: Mc, Graw Hill.

Bruner L, Philip. Introduction. In Elmore 1, Franklin, et.al (ed). 2013. Fundamentals of Construction Law 2nd Edition. United States of America: American Bar Association Publishing.

Burham, J. Scott.1993. Drafting Contract, the Second Edition. United States of America: Michi Company.

Campbell, Dennis. 1996. Structuring International Contract. London: Kluwer Law International.

Fellow, R. F., and Hancock, R. 1994. "Conflict resulting from cultural differentiation: An investigation of the new engineering contract', Rotterdam: Council of International Construction Research and Documentation Proc. on Construction Conflict: Management and Resolution.

Fenn, P., (et.al). 1998. Dispute resolution and management in construction: An international review. London: E\&FN Spon.

Goodpaster, Gary. 1995. Settlement Disputes In Fundamental of Arbitration Economic in Indonesia. Jakarta: Penerbit Ghalia Indonesia.

Gwynne, Richard., and Stephenson Harwood. 1996. "Governing Law and Disputes Resolution" on Dennis Campbell (Ed), Structuring International Contract. London: Kluwer Law International.

Hansen, Seng. 2015. Manajemen Kontrak Konstruksi. Jakarta: PT. Gramedia Pustaka Utama.

Haris, Alan E. 2013. "Alternative Dispute Resolution in 21st Century." on L.Franklin Elmore, (eds). (2013). Fundamental of
Construction Law, 2nd Edition. United States of America: ABA Publishing.

Jane, Jenkins. 2013. International Construction Arbitration Law, Second Revised Edition, Netherlands: Kluwer Law International BV.

Merrils, J.G. 1998. International Disputes settlement, Third Edition. United Kingdom: Cambridge University Press.

Kelley, Gail S. 2016. Construction law: An Introduction for Engineers, architects, and contractors. Canada: John Wiley \& Sons, Inc. p. 51.

Kusumadara, Afifah. 2013. Kontrak Bisnis Internasional Jakarta: Sinar Grafika.

Marzuki, Peter Mahmud. 2006. Metode Penelitian Hukum, Second Edition. Jakarta: Prenada Media Grup.

Miru, Ahmadi. 2007. Hukum Kontrak dan Perancangan Kontrak. Jakarta: PT. Raja Grafindo Persada.

Nugroho, Susanti Adi. 2009. Mediasi sebagai Alternative Penyelesaian sengketa. Jakarta: PT. Telaga Ilmu Indonesia.

Romsan, Achmad. 2016. Alternative Penyelesaian Konflik. Malang: Intrans Publishing.

Stokes, McNeil. Construction Contract, Second Edition. New York: McGraw Hill.

Sudiarto. 2015. Negosiasi, Mediasi, dan Arbitrase, Penyelesaian Sengketa Alternative di Indonesia. Bandung; Pustaka Reka Cipta.

Yasin, Nazarkhan. 2003. Mengenal Klaim Kontruksi di Indonesia dan penyelesaian Sengketa Konstruksi. Jakarta: Gramedia Pustaka Utama. 


\section{Journals}

Cheung, Sai-on. 1998. "Critical factors affecting The Use of Alternative Disputes Resolution Process in Construction." International Journal of Project management. 17 (3).

Cheung, Sai-On. 1999. "Critical Factors Affecting The Use Of Alternative Dispute Resolution Processes in Construction." International Journal of Project Management 17.3.Coulson, Robert. Book Review on Construction Contract by McNeil Stokes 1980. Arbitration Journal. 36 (3).

Djatnika, Suntana S. 2017. Disputes in Construction Contract. BANI Arbitration Quarterly Newsletter. Vol. 9.

Chan, Edwin h. W., and Raymond Y. C. Tse. 2003. "Cultural Consideration in International Contract." Journal of Construction Engineering and Management.

Hasan, Majedi. 2014. "Dispute Resolution Mechanism under FIDIC Form of Contract." BANI Indonesia Quarterly Newsletter. 6.

Nurhidayatuloh, et al. 2018. "Forsaking Equality: Examine Indonesia's State Responsibility on Polygamy to the Marriage Rights in CEDAW." Jurnal Dinamika Hukum. 18 (2).

Romsan, Achmad, et al. 2017. "Climate Change and Community Environmental Conflicts: Are They Correlated?" Sriwijaya Law Review. 1 (1).
Yuanitasari, Deviana, 2017, "The Role of Public Notary in Providing Legal Protection on Standard Contracts for Indonesian Customer." Sriwijaya Law Review. 1 (2).

\section{World Wide Web}

"Adjudication" at http: //www.fenwickelliot.co.uk/ (retrieved April 27, 2018).

Disputes Resolution Technique in construction. 2003. Available online from https://www.lawteacher.net/free-lawessays/contract-law/dispute-resolutionstechnique-in-construction-contract-lawessay.php (retrieved June 4, 2017).

\section{Laws}

FIDIC Conditions of Contract for design, Build and Operate Projects, General Conditions Particular Conditions and Sample Form. First Edition. 2008.

Indonesian New Regulation No. 2 Year 2017 on Construction Activity

PMBOK Guide. 2008. A Guide to Project Management Body of Knowledge, Ed. 4. Pennsylvania: Project Management Institute Inc.

U.N. Doc. A/CN.9/180, Note 17, H 6; UNCITRAL Conciliation Rules, Note 18, art. 13 (3); ICC Conciliation Rules.

Unidroit Principles. 